\author{
$8^{\text {th }}$ LUMEN International Scientific Conference \\ Rethinking Social Action. Core Values in Practice | \\ RSACVP 2017 | 6-9 April 2017 | Suceava-Romania
}

\title{
Dependent Activities vs. Independent Activities in Application of VAT Rate to Individuals
}

\author{
Marta - Claudia CLIZA ${ }^{1}$
}

Abstract

Applying the Fiscal Code in reference to the VAT issue to individuals has raised many controversies in practice. This case study is considering the applicability of VAT against an individual who bas assigned certain patent rights to a legal entity and then, willingly becoming a VAT payer. In these circumstances, the fiscal authorities calculated penalties between the moment the individual registered as a VAT payer and the moment the VAT would have actually been due. However, it has turned out in court that the VAT was not due at all.

Keywords: VAT, dependent activities, independent activities, courts, fiscal authorities.

\section{Introduction}

This article considers a theoretical and jurisprudential research on the classification of an activity as dependent or independent, according to the provisions of the Fiscal Code. In this respect, we conducted a case study in order to prove the importance of such classification, in terms of natural persons' obligation to register and pay the value added tax for the earned income.

Therefore, we will consider both the nature of the income earned under the intellectual property rights assignment agreements, and whether

\footnotetext{
1 Associate Professor PhD, Faculty of Law, „Nicolae Titulescu” University of Bucharest, Romania (cliza_claudia@yahoo.com). 
the provisions on the registration for value added tax purposes, together with all the related consequences, are applicable.

Firstly, we will present the factual situation that effectively generated the case, with reference to industrial property rights in the employeeemployer relationship, from the point of view of applying VAT. We will continue by analyzing the legal nature of revenues obtained through industrial property rights assignment contracts. The third hypothesis will look at the issue of VAT registration, more precisely if a person who has earned income, being employed, as a result of an industrial property rights assignment contract, is required to register for VAT purposes or not.

Although VAT can only be due for operations that are taking place or are considered to be taking place in Romania, the international and social relevance of the subject cannot be denied. Thus, thousands of operations are performed on a daily basis that can be subject to VAT or not. Romanian citizens residing outside Romania, as well as foreign individuals, regardless of where they are domiciled, are subject to taxation in Romania, only for their income in Romania. Thus, it is imperative that the persons doing such operations should have a very clear view of whether or not they pay VAT, as well as whether they should register as VAT payers, depending on the type of activity they may be involved in.

\section{Problem Statement}

So far, a series of manuals, treaties and articles, which include in their scope the concept of value added tax, were drawn $u^{2}$. Notwithstanding, the works of the authors are usually limited to the stating and development of the legal provisions, without reference to a practical case, in order to show, by way of example, the way jurisprudential orientation developed until the respective point in time.

The novelty of this study lies in the fact that it adjusts theoretical elements to an actual case study, in order to show the importance of an appropriate and legal determination of the legal nature of the income earned by a natural person, in case of an agreement for assignment of the rights resulting from patents, therefore from copyrights.

The specialty literature continues to be an open space for debate and addressing questions to which either doctrine or the court's practice will have to answer. However, to this day, although it has been written on VAT, there is no unitary and realistic positioning over the practical problems encountered, such as the subject addressed in this paper. In the specialized

\footnotetext{
${ }^{2}$ Hereinafter referred to as the "VAT".
} 
treaties, there is nothing more than to differentiate the dependent activities from the independent ones, strictly theoretically, without a practical application on the various types of cases encountered. For this very reason, we chose a rather practical approach, since the theories have already been exposed, but not without leaving room for interpretation, considering the multitude of existing case files and the fact that each file has its own specificity and will need to be approached accordingly.

As long as the legal provisions are not applied unitarily, we will witness the multiplication of trials which should have not reached this stage. As we will show, the conclusion of this research targets both the opinion of the courts of law and the way the National Agency for Fiscal Administration could interpret the related legal provisions.

\section{Aims of the research}

The scope of the research is to provide the necessary means to theoreticians, practitioners, and especially to the authorities which collect the taxes, in order to perform a clear analysis on the obligation to register as VAT payers. It is well known that this obligation is subject to certain conditions, despite this, they should not be applied mechanically, but all the elements of a case must be taken into account.

This study aims to clarify the issues which can lead to future litigations, so that the issues will no longer be subject to different interpretations. The predictability of the law is a fundamental principle, which is why we considered that such a research is required, all the more so as we noticed that fiscal bodies tend to provide interpretations which are not entirely in accordance with the related regulations.

In order for this not to become a practice and in the end to prejudice individuals who would fall or not under the scope of the concept of value added tax payer, it is more than required to settle a legal issue that seems to persist.

Therefore, we will define the criteria of differentiation of dependent activity from independent activity and then, we will establish the appropriate legal nature of income resulting from intellectual property rights assignment agreements. Therefore, we will analyze in what conditions this type of income is not part of the income for which a natural person should register as VAT payer. 


\section{Research Methods}

In order to draw up this study, the interpretative method was used in particular. Therefore, we analyzed from a critical point of view the following: Judgments handed down by courts in relation to the issue of applying VAT to a physical person; Specialty articles, including books, treaties, in a printed or electronic form, which have shown relevance; Incidental legal provisions, an occasion where we decided to apply not only a grammatical interpretation, but also a way of thinking that respects the law in its spirits too, not just its letter; Opinions of the fiscal authorities regarding the application of the VAT to individuals.

When we study a legal phenomenon, the first step is to analyze the regulations governing the respective field, namely the provisions of the Fiscal Code. The second step is to analyze certain rulings pronounced either by Romanian courts or by foreign courts.

The objectives of this paper are to ensure that the value added tax is legally applied, regarding strictly individuals. Consequently, we sought to provide clear criteria for differentiating between dependent and independent activities, in order to provide a vision that prevents any kind of prejudice when VAT is applied, regardless of which categories of readers we address, namely: practitioners, individuals interested in the subject, or even the authorities that apply the VAT. Thus, the primary objective is to provide the means necessary for a correct and equitable application, in the spirit and letter of the law, with the ultimate scope of avoiding abuses and not the law itself, but applying the incumbent legal provisions.

Taking into account all the aforementioned, we could reach a pertinent conclusion on the conditions that have to be fulfilled by the income earned by natural person in order to establish whether he has to register as VAT payer.

\section{Findings}

\subsection{Dependent activities vs. independent activities.}

The capacity of taxable person [1] is held by any person who performs independently economic activities [2], regardless of the scope or the result of these activities. Therefore, the classification of an activity as being dependent or independent is required, both in order to establish the taxes that the respective person shall owe, but also in order to avoid paying undue amounts. 
The Fiscal Code defines in art. 7 the activity as being carried out by a person in order to obtain income. Notwithstanding, we cannot ignore the classification given by the same regulation, namely a differentiation is made between independent and dependent activity.

In what concerns dependent activity, persons who derive income in this way shall be regarded as employees, being in a position of subordination to an employer [3]. The definition granted by the law is useful in order to identify salary income, for which VAT shall not be due.

Independent activity, on the other hand, was defined as being any activity carried out regularly by a natural person, other than a dependent activity[4].

The Fiscal Code regulates the obligation of the taxpayers to register for VAT purposes only for persons who carry out economic activities independently, according to art. 127 para. (1). In this respect, the Fiscal Code and Directive 2006/112/EC provide that two categories of persons do not act independently in terms of VAT:

(a) persons who carry out the activity under an employment agreement, respectively,

(b) persons who carry out the activity under another type of agreement, but who create legal relationships similar to those under an employment agreement.

According to the provisions of art. 127 of the Fiscal Code and those of art. 9 and art. 10 of Directive 2006/112/EC, in what concerns the situation of the plaintiff, who derived income from copyrights, it can be concluded that the capacity of taxable person for VAT purposes is not established automatically, but it is conditioned by the performance of an independent activity, as it is regulated by the text of the law, and that the income generating legal relationship has to be analyzed specifically.

Any activity can be reconsidered as dependent activity if it fulfills at least one of the following criteria:

a) the income beneficiary is in a relation of subordination to the income payer, respectively the management bodies of the income payer, and fulfills the labor conditions established by the latter, such as: duties and duties fulfillment modalities, the place of work, working program;

b) in carrying out the activity, the income beneficiary uses exclusively the materials of the income payer, respectively appropriate usage spaces, special work or protection equipment, work tools or other similar and contributes with physical performance or intellectual ability, and not with own capital; 
c) the income payer bears in the benefit of the performance of the activity the travel expenses of the income beneficiary, such as allowance for being detached in the country and abroad, and other similar expenses;

d) the income payer bears leave allowance and temporary work disability allowance, in the income beneficiary's account.

Therefore, the income derived by the plaintiff from copyrights was derived under an employee-employer dependent relationship, and therefore, the income is not subject to VAT related provisions.

\subsection{Intellectual property rights in Employee-Employer relationship.}

\subsubsection{De facto situation generating this research.}

Throughout 2006 - 2011, the plaintiff, as inventor/assignor obtained income from the employer company, under certain contracts / agreements of intellectual property rights assignment. The agreements concerned patent rights the registration of which was performed upon the request of the employer company. Throughout the same period (i.e. 2006 - 2011), the plaintiff held the capacity of employee of the company in question, under an individual labor agreement ${ }^{3}$ [5], in the position of chemical engineer. In the "normal" performance of the work, the employee fulfilled the following duties: the monitoring of observance of manufacturing and operating technologies of specific installations, chemical installations design and the approval of the processes for the production of various chemicals.

The plaintiff proceeded voluntarily with the registration for VAT purposes due to the fact he misunderstood the fiscal provisions. When he realized that the registration was not required, he initiated correspondence with the Regional Directorate of Public Finance in order to repay him the amount paid, without this amount being due. The authority considered that tax obligations were established and recorded on own initiative, thereby refusing the plaintiff's request. The latter resorted to the competent court of law which admitted his petition, thus ordering the repayment of the amount paid as VAT.

\subsubsection{The legal nature of the income obtained under the intellectual property rights assignment agreements.}

Given the above facts, the first observation that, at the same time, the employer company held both the capacity of employer and the capacity

\footnotetext{
3 ,The individual labor agreement is the agreement under which the natural person, called employee, undertakes to perform the work for and under the authority of an employer, natural person or legal entity, for a remuneration called salary".
} 
of assignee of the intellectual property rights, and the plaintiff held both the capacity of employee and the capacity of inventor/assignor.

Furthermore, both relations relied on the plaintiff's specialization of chemical engineer, an aspect that cannot be challenged as long as it results from the content of the individual labor agreement, but it can also be derived from the content of the patents, respectively the activities carried out in order to achieve the processes contemplated by them.

Therefore, under the concluded Agreement, the employer company, as assignee/beneficiary, was granted the exclusive exploitation of the intellectual property rights in connection with certain technical-technical processes. These assigned processes were developed by the plaintiff together with a group of inventors, within a long period of time, by using the materials and the research means provided by the employer company, by holding, at the same time, the capacity of employees.

It is obvious that the development of these processes involved a significant period of time and required equipment, tools and raw materials, incompatible with research on their own, as well as the simultaneous fulfilment of work duties related to employment.

The processes invented by the plaintiff required equipment, tools and substances which could only be found in petrochemical industry. Therefore, it is hard to believe that these results could be reached by improvising an own „laboratory”, due to the fact the costs are huge and the sizes of the respective equipment cannot be neglected. Therefore, the process could not take place somewhere outside the research laboratories of a chemical plant, the latter being equipped with all materials required in order to fulfil such a process.

Regarding the legal provisions applicable in this case, the provisions on the income from independent activities, as well as on salary income are relevant in particular, as follows:

The salary income referred to in art. 55 of the Fiscal Code is dependent activity income if the following criteria are fulfilled:

- the parties in the employment relationship, hereinafter referred to as the employer and the employee, establish from the beginning the following: the type of activity, working time and place of work;

- the party using the work force provides the other party the means of work, such as: properly equipped spaces, special clothing, work tools and others similar;

- the working person contributes only with physical performance or intellectual capacity, not with own capital; 
- the salary income payer bears employee's travel expenses, such as allowance for being detached in the country and abroad, and other similar expenses, as well as leave allowance and work temporary disability allowance borne by the employer according to the law;

- the working person works under the authority of another person and shall be bound to fulfill the conditions established by the employer, according to the law.

The analysis of the definition of salary income and independent activities income, in connection with the provisions of items 19 and 67 of the Methodological Regulations for the application of the Fiscal Code, leads to the conclusion that the income derived by the plaintiff, under the agreements, is assimilated to salary income in connection with the provisions of art. 55 of the Fiscal Code. If our interpretation of the legal provision was in an opposite direction, this would mean that we ignore one of the basic principles applicable in the tax field, namely the principle of prevalence of substance over form [6].

Furthermore, both the European Court of Justice and the National Supreme Court established by their case law the fact that public authorities cannot restrict individual rights or establish obligations based on purely formal grounds, unless they are doubled by grounds related to the substance of social relations they are addressed to[7].

Therefore, despite that the relations between the plaintiff and the employer company were regulated by distinct and specific documents (individual labor agreement, agreements on assignment of intellectual property rights), the activity carried out in order to develop the respective chemical processes was encouraged both financially and materially by the employer company. This activity overlapped entirely the current activity carried out by the plaintiff, as chemical engineer, employee. Therefore, the provisions of item 24 of the methodological regulations are applicable, in the application of art. 46 of the Fiscal Code, in connection with art. 55 of the Fiscal Code.

\subsubsection{Registration for VAT purposes.}

A person is considered taxable [8] in terms of value added tax under the provisions of art. 127 and the following of the Fiscal Code if the respective person performs independently economic activities of sale of goods or provisions of services, on a continuing basis. The legislation is supposed to be predictable and not to create different interpretation possibilities, especially in connection with the sanctions [9] which shall be 
incurred by a person who had to register for VAT purposes, but who failed to do so.

According to the provisions of art. 134 para. (1) of the Fiscal Code, the generating fact is the moment when a sale of goods or a provision of services for which VAT has to be paid occurs. According to art. 134 para. (2), the maturity date of the VAT is the date when the tax authorities can request the payment of the tax.

If the copyright assignment [10] results in a dependent relation between the assignor - plaintiff - and assignee - employer company namely an employee-employer relation, the independence condition is not fulfilled anymore, therefore the respective person shall not be taxed in terms of the value added tax.

Furthermore, the activities listed in para. 2 of art. 127, exempt salary income from VAT taxation, and in this case the income derived under the agreements contemplates intellectual property rights assignment and it has in fact the nature of salary income, therefore, it is not subject to taxation in terms of value added tax.

\section{Conclusions}

Therefore, the need for an appropriate classification in a certain type of activity can be noted. If an independent activity had been performed, which is not similar to employee-employer relation, the payment of the VAT for derived income would have been required. But, as long as the plaintiff concluded a labor agreement with the employer company, developed the respective processes by using the materials made available and by virtue of the duties that he had in the company where he was employed, it can be unquestionably concluded that such income will have salary nature.

Therefore, given all the matters largely developed by reference to de facto and de jure considerations that we hereby presented, the following conclusions can be drawn, which were also noted by the court of law [11] which admitted the plaintiff's petition: (i) the income derived by the inventor/assignor under the intellectual property rights assignment agreement is income obtained from salary and (ii) this income is not subject to taxation in terms of value added tax. 


\section{References}

[1] Resolution of June 26 $6^{\text {th }}, 2007$, T-Mobile Austria and others, C-284/04, p. I5189, item 33, available on eur-lex.europa.eu, site accessed on March $20^{\text {th }}$, 2017.

[2] Case C-369/04, Hutchison 3G UK Ltd and others against the Commissioners of Customs and Excise, available on eur-lex.europa.eu, site accessed on March 20th 2017.

[3] Costea, I. M. Fiscalitate europeana. Note de curs. Bucharest: Hamangiu Publishing House; 2016. 117.

[4] Singeorzan, D-E. Taxe si impozite. Dobanzi si penalitati in materie fiscal. Practica judiciara. Bucharest: Hamangiu Publishing House; 2011. 118.

[5] Uta, L, Rotaru, F, Cristescu, S. Codul muncii adnotat: legislatie, jurisprudenta nationala si comunitara, doctrina si comentarii. Bucharest: Hamangiu Publishing House; 2009.

[6] Niculeasa, M-I. Summa fiscalis. Tratat de drept fiscal si financiar public. edition III, revised and supplemented. Bucharest: Universul Juridic; 2014. 780.

[7] The High Court of Cassation and Justice - Decision no. 2041/2007; Court Case Collee C 146/05; The High Court of Cassation and Justice Decision no. $1147 / 2009$.

[8] Costea, I. M. Drept financiar. Note de curs. Conform noului Cod fiscal si noului Cod de procedura fiscal. Bucharest: Hamangiu Publishing House; 2016. 102.

[9] Bufan, R. Tratat de drept fiscal. Volumul I. Teoria generala a dreptului fiscal. Bucharest: Hamangiu Publishing House; 2016. 419: the sanctions shall take into account the proportionality principle of the European Union law.

[10] Piperea, G, Armasu, I. Plata TVA la cesiunea drepturilor de autor. Intre legalitate si ilegalitate (I). Revista Romana de Drept al Afacerilor no. 7 of 2012.

[11] Civil sentence no. 394/2016, pronounced by Tribunal of Valcea, Civil division II on March 9 ${ }^{\text {th }}, 2016$. 
Available online at: http://lumenpublishing.com/proceedings/published-volumes/lumenproceedings/rsacvp2017/

$8^{\text {th }}$ LUMEN International Scientific Conference Rethinking Social Action.

Core Values in Practice | RSACVP 2017 | 6-9 April 2017 |

Suceava - Romania

\title{
Rethinking Social Action.
} Core Values in Practice

\section{Dependent Activities vs. Independent Activities in Application of VAT Rate to Individuals}

\author{
Marta - Claudia CLIZA \\ https://doi.org/10.18662/lumproc.rsacvp2017.17
}

How to cite: Cliza, M. - C. (2017). Dependent Activities vs. Independent Activities in Application of VAT Rate to Individuals. In C. Ignatescu, A. Sandu, \& T. Ciulei (eds.), Rethinking Social Action. Core Values in Practice (pp. 176-185). Suceava, Romania: LUMEN Proceedings https://doi.org/10.18662/lumproc.rsacvp2017.17 